\title{
Expanding Role of Self Expanding Esophageal Stents
}

\author{
Kulwinder S Dua \\ Director, Advanced GI Endoscopy Fellowship, Medical College of Wisconsin, Milwaukee, USA
}

\begin{abstract}
Esophageal cancer is often diagnosed at a late stage and hence carries a poor prognosis with an overall 5-year survival rate of $10 \%$ to $15 \%$. Therefore, palliative treatment primarily aimed at the relieving dysphagia is the only available option. Endoscopic placement of self expanding metal stents (SEMS) has become a widely used method for palliation offering prompt relief of dysphagia and numerous reports have shown it to be safe and effective. Secondary to tissue in-growth into the uncovered segments of the stent, SEMS cannot be removed and hence are not approved for benign indications. With the advent of the removable self expanding plastic stents, the indications for esophageal stent insertion have expanded to as bridge to surgery for patients undergoing neoadjuvant chemotherapy, for refractory benign esophageal strictures, for nonmalignant esophageal perforations, leaks and fistulae, and even for variceal hemorrhage. Newer fully covered SEMS that are potentially removable are also being tried for benign indications but await FDA clearance. Similarly biodegradeable stents for benign disorders and radioactive or drug-eluding stents for malignant disease are hoped to improve the management of esophageal diseases. The purpose of this article is to review the expanding role of self expanding stents in the management of esophageal disorders other than palliating malignant dysphagia and fistulae.(J Dig Endos 2011;2(1):9-14)
\end{abstract}

Keywords: Esophageal cancer - Malignant dysphagia - Refractory benign esophageal stricture - Esophageal perforation leaks Fistulae - Self expanding metal stent - Self expanding polyflexstent - Biodegradeable esophageal stent

With the introduction of self-expanding metal esophageal stents (SEMS), interest in using stents as a palliative option for malignant dysphagia was revived and currently SEMS have virtually replaced the older semi-rigid plastic stents which were associated with high complication rates. [1-5] Some of the advantages of SEMS over semi-rigid plastic stents are thinner delivery system as the stent is constrained to a small diameter; hence pre-insertion dilatation is not required in most patients. Despite the thinner delivery system, the expanded stent can reach diameters larger than the semi-rigid plastic tubes and the expansion is gradual unlike the abrupt stretching from plastic stents. SEMS can conform to the shape of the stricture and hence are ideal for tortuous strictures. It is easy to place SEMS within SEMS if needed. SEMS are covered with a plastic membrane to prevent tissue in-growth but also have partially uncovered segments at the proximal and distal ends for better anchoring with tissue in-growth. Once embedded, they are difficult to remove. Hence SEMS are not FDA cleared for benign indications. However, in the recent past, a self-expanding plastic esophageal stent (SEPS) was introduced (Polyflex stent ${ }^{\circledR}$ ). This stent is made of woven plastic strands (potentially induces less tissue reaction compared to metal) and the stent is fully covered. Due to these features, this stent can be removed and is also approved for benign strictures. Fully covered metal stents (potentially removable) are also now available and are awaiting FDA clearance for benign indications.

Reprints requests and correspondence:

Kulwinder S Dua,

MD, FRCP (Edin), FACP, FRCP (London), FASGE

Professor, Department of Medicine

Chief, Division of Gastroenterology \& Hepatology, VAMC

Director, Pancreaticobiliary Center, DDC

Director, Advanced GI Endoscopy Fellowship

Medical College of Wisconsin, Milwaukee, U.S.A

Kdua@mcw.edu

Received: 21 st Sept 2010

Accepted: 29th Nov 2010 
Since the efficacy and safety of expandable stents in palliating advanced malignant dysphagia and fistulae have been well studied and extensively published, this review will focus only on the relatively recent concepts and indications of using SEMS and SEPS in the management of esophageal disorders.

\section{Bridge to Surgery}

Traditionally, SEMS and SEPS are used for palliating advanced in-operable esophageal cancers with the intentions o

f improving quality of life by maintaining an open and functional oro-gatric pathway until the patient's demise. Their role in patients with resectable disease or those needing neoadjuvant therapy before surgery is not well established. Around $40 \%-50 \%$ of patients fall in this category and almost all present with dysphagia requiring symptom relief. These patients may have to wait for several weeks before surgery, either receiving neoadjuvant therapy or on the wait-list for surgery. There has been some apprehension on placing SEMS in these patients for fear of complications, especially if they are receiving neoadjuvant treatment. This apprehension is based on some studies showing a higher complication rate with SEMS in those who have received prior chemoradiation. [6,7] Hence, unfortunately these operable patients on neoadjuvant treatment receive a naso-gastric or a PEG tube as a bridge to surgery. Neither of these approaches relieves dyphagia. Naso-gastric tube can be uncomfortable and PEG tubes are not without risks besides the fact that they may interfere with subsequent gastric pull-up surgery. Hence using stents to relieve dysphagia as a bridge to surgery appears to be an attractive option.

Studies to evaluate the efficacy of stents during neoadjuvant therapy for locally advanced esophageal cancer prior to surgery are limited.[8-10] In a recent prospective study,[8] 13 patients with dysphagia who were found to have locally advanced, non-metastatic esophageal cancer on endoscopic ultrasound had a SEPS (Polyflex stent) placed at the time the ultrasound was performed. These patients were considered candidates for neoadjuvant therapy prior to surgery. All patients had significant improvement in dysphagia scores (3 at baseline compared to 1.1, 0.8, 0.9, and 1.0 at 1, 2, 3, and 4 weeks after stenting respectively). Except for one patient with severe chest pain, there were no immediate complications. However, the stent migrated in 6 of 13 patients (46\%). Only 3 of 13 patients eventually underwent esophagectomy.

Although the above approach appears attractive compared to naso-gastric or PEG tube placement, it is important to understand that stents do not prolong survival and hence the only rationale to use this approach will be to immediately relieve dysphagia and allow for natural eating while the patient is waiting for definitive therapy. However, experience from stenting advanced cancers for palliation has
Table: *POLYFLEX STENT. (Boston Scientific, Inc) used for benign esophageal stricture, fistulae, leaks and perforations.

$\begin{array}{lcc}\text { Length } & \begin{array}{c}\text { Internal } \\ \text { diameter }\end{array} & \begin{array}{c}\text { Delivery system } \\ \text { diameter }\end{array} \\ 90 \mathrm{~mm}, 120 \mathrm{~mm}, 150 \mathrm{~mm} & 16 \mathrm{~mm} & 12 \mathrm{~mm}(36 \mathrm{~F}) \\ 90 \mathrm{~mm}, 120 \mathrm{~mm}, 150 \mathrm{~mm} & 18 \mathrm{~mm} & 13 \mathrm{~mm}(39 \mathrm{~F}) \\ 90 \mathrm{~mm}, 120 \mathrm{~mm}, 150 \mathrm{~mm} & 21 \mathrm{~mm} & 14 \mathrm{~mm}(42 \mathrm{~F})\end{array}$

*Polyflex stent is the only stent cleared by FDA for treating benign esophageal strictures.

shown that a significant proportion of these patients may develop stent-related complications. [11] If these also occur in operable patients, it may delay or interfere with chemoradiation or surgery. Stent related perforation could be disastrous as this may spill malignant cells into the mediastinum or the peritoneal cavity. Although there are studies showing higher complication rates with stents in those who have received prior chemo-radiation, [6,7] there are very few studies looking at the complication rates of stents in those who receive chemo-radiation after stent placement. In one study,[12] of the 3 patients who received SEMS before radiotherapy, one died of perforation 2 months after radiotherapy. In another study on patients receiving radiotherapy 1 week after stenting, elective removal of the stent at 4 weeks was associated with less complications compared to those in whom the stents were not removed.[13] There are no randomized studies looking at the influence of stents on subsequent surgery e.g., difficulties during surgery, anastomotic leaks etc. Similarly no data is available on which type of stent will be ideal in this situation: SEPS (higher complication rate), fully covered SEMS, or biodegradable stent. Lastly, undernourished individuals on chemo-radiation may become more anorectic and not eat despite a stent.

Based on limited studies and some of the issues mentioned above, currently one cannot routinely recommend placing esophageal stents during neoadjuvant therapy as bridge to surgery.

\section{Refractory Benign Esophageal Strictures}

Traditionally, endoscopic dilatation with a bougie or a balloon is the method of choice for treating benign esophageal strictures. Around $40 \%$ of benign strictures recur[14] and require periodic dilatations. Complex strictures defined as $>2 \mathrm{~cm}$ in length with tortuous configuration and tight enough not to allow a standard endoscope to pass, are difficult to dilate, carry a higher procedural complication rate and tend to recur within weeks.[15,16] Corrosive injuries, radiation, surgery, and esophageal ablative treatments like photodynamic therapy and mucosal resections can lead to the formation of complex strictures. These strictures are hence characterized as Refractory Benign Esophageal Strictures (RBES). The term RBES 
was loosely used in the past but currently the most accepted definition is an anatomic fibrotic esophageal restriction, absence of inflammation or motility disorder, with inability to achieve a diameter of $\geq 14 \mathrm{~mm}$ in five sessions of dilatations at 2-week intervals or inability to maintain a diameter of $\geq 14 \mathrm{~mm}$ for 4 weeks once $\geq 14 \mathrm{~mm}$ diameter is achieved. [17] Until now, high-risk dilatations, surgery with associated morbidities and mortalities or life-long G-tube feedings were some of the only alternatives left for these unfortunate patients. Recently newer endoscopic approaches like using expandable esophageal stents have been tried but there are no major prospective randomized studies comparing their efficacies and most of the data available are based on small series.

\section{The Concept of using Stents}

If a few seconds of stretching with a bougie or a balloon can give relief for several weeks, then stretching continuously for several weeks conceptually may give longer lasting benefits. This may give enough time for the tissue to remold around the dilator. Expandable esophageal stents are ideal in stretching the stricture continuously for weeks while maintaining luminal patency. However, unlike malignant strictures, the stent should be a removable stent if used for benign indication. Self-expanding esophageal stents that have been tried for RBES are metal stent (partly covered and fully covered), plastic stents and biodegradable stents.

\section{Partly Covered Self-expanding Esophageal Metal Stent}

SEMS are usually coated with plastic to prevent tumor in-growth and have short uncovered segments at the proximal and distal ends for tissue in-growth to allow for better anchoring. Although this feature reduces the risk of stent migration it makes removal of the stent difficult and high-risk. This may not be an issue for those where SEMS are placed permanently for palliation of advanced malignant dysphagia. For RBES, if stents are not removed, they may erode into the mediastinum including the aorta. Other significant complications with long-term stenting include ulceration, bleeding, fistula and recurrent dysphagia due to migration, granulation tissue and new stricture formation. Hence partly covered SEMS are not FDA cleared for use in benign strictures. Nevertheless, there are several small retrospective series in the literature where these stents were used for RBES with very poor results. In review of 29 patients where SEMS were placed for RBES, the overall complication rates noted were up to $80 \%$ which included new stricture formation (40\%), migration (31\%), and trachea-esophageal fistula (6\%).[18] In another smaller series, 4 of 8 patients, developed major complications and one patient died from bleeding secondary to the stent eroding into the aorta.[19] Similar discouraging results have been noted in several other

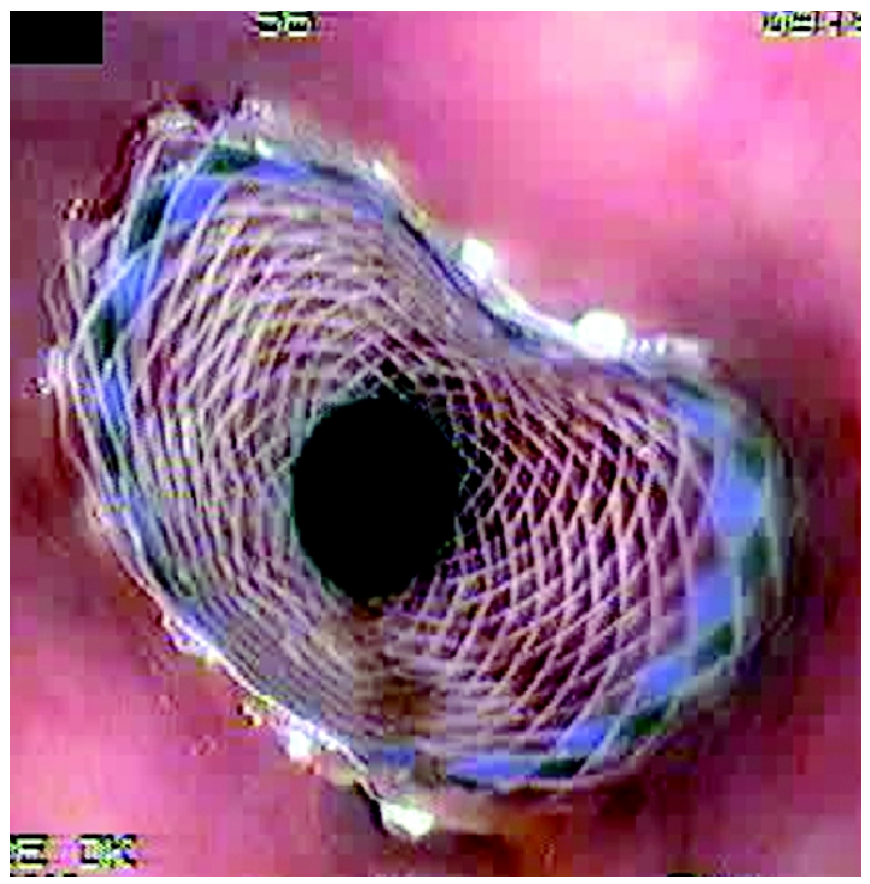

Figure 1: Polyflex fully covered expandable esophageal plastic stent (Boston Scientific; FDA cleared for use in benign esophageal strictures)

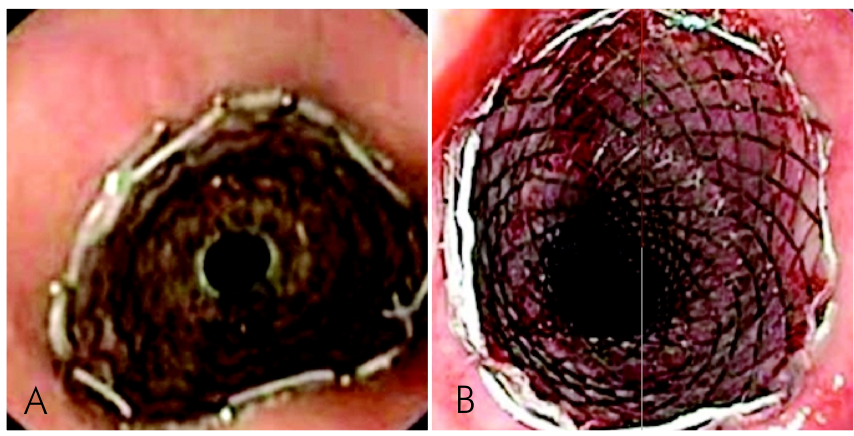

Figure 2: (A) Alimaxx-E fully covered expandable esophageal metal stent (Merit Inc; not FDA cleared for benign esophageal disorders). (B) Wallflex fully covered expandable esophageal metal stent (Boston Scientific Inc; not FDA cleared for benign esophageal disorders)

small series. [20-22] Besides not being approved for benign indications, and due to unacceptable complication rates, partially covered SEMS are not recommended for RBES.

\section{Self-expanding Esophageal Plastic Stents}

A fully covered self-expanding plastic esophageal stent (POLYFLEX ${ }^{\circledR}$, Boston Scientific Corporation, MA, USA) is now available and FDA cleared it for removal indications. This stent is made of polyester mesh with an outer covering of a silicone membrane. Since plastic material induces less granulation tissue reaction and the full covering prevents tissue in-growth, this stent is removable and hence can be used for benign esophageal strictures. 
Initial success rates reported on its efficacy in treating benign esophageal strictures were as high as $80 \%$ with minimal complications.[23-25] Subsequent studies form other centers could not reproduce these results.[26,27] On the contrary, these subsequent studies showed poor cure rates with significant associated complication rates which included migration, hemorrhage, chest pain, ulceration and esophageal perforation. These variable results could be due to these studies enrolling patients with different definitions of RBES, variable periods for which the stents were kept in place and the retrospective nature of the design.

In a recent prospective study,[28] 40 patients fulfilling the definition of RBES[16] were enrolled. A SEPS (Polyflex) was deployed across the stricture and then removed after 4-6 weeks of continuous dilatation. At a median of 53 weeks follow up, $30 \%$ of patients were dysphagia-free. Another $30 \%$ of patients with recurrence of dysphagia after stent removal opted for reinsertion of a new Polyflex stent for a longer duration rather than going back to their baseline alternatives of repeated frequent dilations, G-tube feeding or surgery. Hence, this approach was able to change the outcomes from baseline alternatives in over $50 \%$ of patients. Unfortunately complications in the form of migration, chest pain, bleeding and perforation were observed in over $30 \%$ of patients and there was a mortality in one patient who refused stent removal and died of severe bleeding probably related to an aorto-esophageal fistula. A recent study compared Polyflex stent to repeated dilations. Both approaches were equally effective in relieving dysphagia but Polyflex stent group required lower number of dilations. [29]

With the available data, it is not clear how the etiology of the RBES influences the outcomes and what is the optimum duration for which the SEPS should be kept in place. This approach is associated with relatively high complication rates and hence should be considered in select patients and that to preferably in a research protocol.

\section{Fully Covered Self-expanding Esophageal Metal Stent}

Some of the fully covered SEMS available in the US are the Alimaxx-E, Merit Co, Colorado, Wallflex, Boston Scientific, MA, and Nitis-S, TaeWoong. As of writing this review, these stents are not FDA cleared for use as removable stents. However, the plastic coating along the full length of the stent prevents tissue in-growth and hence these stents are potentially removable. The wire mesh design can get constrained to a thiner diameter compared to a plastic mesh. Unlike the Polyflex stent, they come pre-loaded and the delivery system is thinner in diameter.

As a proof of principle, studies on pigs, showed that Alimaxx-E stents can be removed.[30] Alimaxx-E stent was successfully placed and removed in a small series of 9 patients and in another small series of 7 patients, the success rate in treating the strictures with this stent was reported to be around $29 \%$.[31,32] Stricture recurrence rate of $40 \%$ has been reported with Nitis-S stent. New stricture formation, migration and broncho-esophageal fistula were some of the complications observed.[33,34] Data of fully covered Wallflex stent for RBES is awaited as of writing this review.

\section{Biodegradable esophageal stents}

Biodegradable stents are made of polylactide/ polydioxanon. These stents are uncovered and hence tissue in-growth can anchor the stent. Once anchored, the stent cannot be removed but this is not a major issue as the material used to make these stents is metabolized and hence these stents are biodegradable. There is limited data on its loss of radial force over time. Initial results on using these stents for RBES has been encouraging. [35] This stent is not approved for use in the US.

\section{Non-Malignant Esophageal Perforations, Leaks, Fistulae}

Esophageal perforation can be spontaneous or iatrogenic. Leaks are generally seen with anastomotic surgery following esophageal resection and these leaks can evolve into fistulae. Early recognition and intervention before mediastinitis sets is the key to improving outcomes. Surgery is still considered to be the primary option in majority of these patients. However, surgery can be associated with significant morbidity and mortality especially in the elderly with multiple medical problems. Covered SEMS or SEPS can offer a minimally invasive alternative to surgery and these stents can be placed at times even as an out-patient procedure. Feedings can be started immediately if radiology study shows no leak. Frequently iatrogenic perforations happen during dilatation of strictures and stents can also be useful in managing the stricture besides the leak.

In a series of 11 patients with traumatic esophageal perforation, stents completely sealed the perforation in 9 patients. In those where the diagnosis was delayed by over 24 hours, chest drains were placed.[36] In another series, perforation closure was successful in 12 of 13 patients within 3 weeks with no complications.[37] In 17 patients with iatrogenic perforations, SEPS sealed the leaks in 16 patients.[38] Similar to iatrogenic and traumatic perforations, stents have also been used for spontaneous perforations (Boerhaave's syndrome) with encouraging results. $[39,40]$ However the case series are much smaller and no firm conclusions can be made. In a recent prospective study, 33 patients with esophageal perforations (iatrogenic 19, Boerhaave's syndrome 10, others 4) were treated with various types of covered expandable esophageal stents. ${ }^{4}$ Complete and immediate sealing of the perforation was observed in $32(97 \%)$ patients. Four patients required esophageal resections for failed therapy. Complication included stent migration (33\%) and technical difficulties in stent extraction in those where the stent was kept in place for over 6 weeks or were partially uncovered. Interestingly the 90 -day mortality rate was $15 \%$. Since this was a non- 
randomized study, comparable mortality rates with surgery in this group is not known.

Expandable stents have also been tried for anastomotic leaks and fistulae. Most of these studies have shown encouraging results (success rates over $80 \%$ ) but no firm conclusions can be made as these are small case series. [42-44]

\section{Variceal Hemorrhage}

In an interesting approach to control refractory variceal bleeding, Wright et al $\mathrm{x}$ treated 9 patients with SEMS. Six of the 9 patients survived the acute bleeding episode and had the stent removed endoscopically at a median of 9 days. Stent failed to control the bleeding in 3 patients, 2 of whom had gastric varices. Although this is an interesting approach, it may not be feasible to apply as stenting and removing stents requires expertise and stent are significantly more expensive than Sengstaken-Blakemore tubes especially when considering third-world countries. Moreover, stent can only tamponade esophageal but not gastric varices. [45]

\section{Conclusion}

Stents were primarily introduced for palliating dysphagia due to advanced esophageal malignancies. With the introduction of expandable esophageal stents that can be removed or have the potential for removability, there has been a great interest in using stent for benign indications. The attraction lies in the fact that stents can be placed and removed endoscopically using minimally invasive techniques, frequently performed as an out-patient procedure, compared to alternatives like surgery that carry a high morbidity and mortality rate. The benefits are immediate but the long-term durability of this benefit is not known. Based on the current literature comprising mostly of non-randomized, retrospective small case series no firm recommendations can be made. Early indications are encouraging for RBES and esophageal perforations, leaks and fistulae. No data in available on the influence of the etiology of the strictures on the outcomes and similarly there are no comparative studies between the various types of stents available in the market. Several studies have reported high complication rates. Hence, patients should be selected carefully weighing the risk-benefit ratios, alternative therapies, and the level of personal expertise in placing and removing most of the available stents. Last but not the least, stents are expensive and this may have a bearing in thirdworld countries where the alternatives to stenting may be cheaper.

\section{References}

1. Domschke W, Foerster EC, Matek W, Rodl W. Self-expanding mesh stent for esophageal cancer stenosis. Endoscopy 1990;22:134-6.

2. Knyrim K, Wagner HJ, Bethge N, Keymling M, Vakil N. A controlled trial of an expansile metal stent for palliation of esophageal obstruction due to inoperable cancer. NEnglJ Med 1993;329:1302-7.

3. Eickhoff A, Knoll M, Jakobs R, Weickert U, Hartmann D, Schilling D, Eickhoff JC. Self-expanding metal stents versus plastic prostheses in the palliation of malignant dysphagia: long-term outcome of 153 consecutive patients. J Clin Gastroenterol 2005;39:877-85.

4. Roseveare CD, Patel P, Simmonds N, Goggin PM, Kimble J, Shepherd HA et al. Metal stents improve dysphagia, nutrition and survival in malignant oesophageal stenosis: a randomized controlled trial comparing modifi ed Gianturco Z-stents with plastic Atkinson tubes. Eur J Gastroenterol Hepatol 1998; 10:653-7.

5. Siersema PD, Hop WC, van Blankenstein M, van Tilburg AJ, Bac DJ, Homs MY, Kuipers EJ. A comparison of 3 typesof covered metal stents for the palliation of patients with Dysphagia caused by esophagogastric carcinoma: a prospective, randomized study. Gastrointest Endosc 2001;54:145-53.

6. Kinsman KJ, DeGregorio BT, Katon RM, Morrison K, Saxon RR, Keller FS, Rosch J. Prior radiation and chemotherapy increase the risk of life-threatening complications after insertion of metallic stents for esophagogastric malignancy. Gastrointest Endosc 1996;43:196-203.

7. Lecleire S, Di Fiore F, Ben-Soussan E, Antonietti M, Hellot MF, Paillot B, Lerebours E. Prior chemoradiotherapy is associated with a higher life-threatening complication rate after palliative insertion of metal stents in patients with oesophageal cancer. Aliment Pharmacol Ther 2006;23:1693702.

8. Adler DG, Fang J, Wong R, Wills J, Hilden K.. Placement of Polyflex stents in patients with locally advanced esophageal cancer is safe and improves dysphagia during neoadjuvant therapy. Gastrointest Endosc 2009;70:614-9.

9. Martin R, Duvall R, Ellis S, Scoggins CR. The use of selfexpanding silicone stents in esophageal cancer care: optimal pre-, peri-, and postoperative care. Surg Endosc 2009;23:615-21.

10. Siddiqui AA, Loren D, Dudnick R, Kowalski T. Expandable polyester siliconcovered stent for malignant esophageal structures before neoadjuvant chemoradiation: a pilot study. Dig Dis Sci 2007;52:823-9.

11. Ross WA, Alkassab F, Lynch PM, Ayers GD, Ajani J, Lee JH, Bismar M. Evolving role of self-expanding metal stents in the treatment of malignant dysphagia and fistulae. Gastrointest Endosc 2007;65:70-6.

12. Yakami M, Mitsumori M, Sai H, Nagata Y, Hiraoka M, Nishimura Y. Development of severe complications caused by stent placement followed by definitive radiation therapy for T4 esophageal cancer. Int J Clin Oncol 2003;8:395-8.

13. Shin JH, Song HY, Kim JH, Kim SB, Lee GH, Park SI, Han YM, Comparison of temporary and permanent stent placement with concurrent radiation therapy in patients with esophageal carcinoma.J Vasc Interv Radiol 2005;16:67-74.

14. Spechler SJ. American Gastroenterology Association medical position statement on treatment of patients with dysphagia caused by benign disorders of the distal esophagus. Gastroenterology 1999;117:229-32.

15. Said A, Brust DJ, Gaumnitz EA, Reichelderfer M. Predictors of early recurrence of benign esophageal strictures. Am J 
Gastroenterol 2003;98:1252-6.

16. Siersemma PD, Wsijkerslooth LR. Dilation of refractory benign esophageal strictures. Gastrointest Endosc 2009; 70:1000-12.

17. Kochman ML, McClave SA, Boyce HW. The refractory and the recurrent esophageal stricture: a definition. Gastrointest Endosc 2005;62:474-75.

18. Sandha GS, Marcon NE. Expandable metal stents for benign esophageal obstruction. Gastrointest Endosc Clin N Am 1999; 9:437-46.

19. Wadhwa RP, Kozarek RA, France RE, Brandabur JJ, Gluck M, Low DE, Traverso LW. Use of self-expandable metallic stents in benign GI diseases. Gastrointest Endosc 2003;58:207-12.

20. Fiorini A, Fleischer D, Valero J, Israeli E, Wengrower D, Goldin E. Self-expandable metal coil stents in the treatment of benign esophageal strictures refractory to conventional therapy: a case series. Gastrointest Endosc 2000;52:259-62.

21. Song HY, Park SI, Do YS, Yoon HK, Sung KB, Sohn KH. Expandable metallic stent placement in patients with benign esophageal strictures: results of long-term follow-up. Radiology 1997;203:131-6.

22. Ackroyd R, Watson DI, Devitt PG, Jamieson GG. Expandable metallic stents should not be used in the treatment of benign esophageal strictures. J Gastroenterol Hepatol 2001;16:484-7.

23. Repici A, Conio M, De Angelis C, Battaglia E, Musso A, Pellicano R, Goss M. Temporary placement of an expandable polyester silicone-covered stent for treatment of refractory benign esophageal strictures. Gastrointest Endosc 2004;60:513-9.

24. Pungpapong S, Raimondo M, Wallace M. Problematic esophageal stricture: an emerging indication for selfexpandable silicone stents. Gastrointest Endosc 2004;60:842-45.

25. Evrard S, Le Moine O, Lazaraki G, Dormann A, El Nakadi I, Devière J. Self-expanding plastic stents for benign esophageal lesions. Gastrointest Endosc 2004;60:894-900.

26. Triester SL, Fleisher DE, Sharma VK. Failure of selfexpanding plastic stents in treatment of refractory benign esophageal strictures. Endoscopy 2006;38:533-7.

27. Holm AN, Levy JL, Gostout CJ, Topazian M, Baron T. Selfexpanding plastic stents in treatment of benign esophageal conditions. Gastrointest Endosc 2008;67:20-5.

28. Dua KS, Vleggaar FP, Santharam R, Siersema PD. Removable self-expanding plastic esophageal stent as a continuous, nonpermanent dilator in treating refractory benign esophageal strictures: a prospective two-center study. Am J Gastroenterol 2008;103:2988-94.

29. Oh YS, Kochman ML, Ahmad NA, Ginsberg GG. Clinical outcomes after self-expanding plastic stent placement for refractory benign esophageal strictures. Dig Dis Sci 2010; 55:1344-8.

30. Baron TH, Burgart LJ, Pochron NL. An internally covered (lined) selfexpanding metal esophageal stent: tissue response in a porcine model. Gastrointest Endosc 2006;64:263-7.

31. Lakhtakia S, Reddy ND, Dua KS. Refractory benign esophageal strictures: continuous, non-permanent dilation with a self-expandable metal esophageal stent (Alimaxx-E).
Gastrointest Endosc 2007;65:AB284.

32. Eloubeidi MA, Lopes TL. Novel removable internally fully covered self-expanding metal esophageal stent: Feasibilty, technique of removal and tissue response in humans. $A m \mathrm{~J}$ Gastroenterol 104:1374-81.

33. Song HY, Park SI, Jung HY, Kim SB, Kim JH, Huh SJ, Kim TH. Benign and malignant esophageal sterictures: treatment with a polyurethane-covered retrievable expandable metallic stent. Radiology 1997;203:747-52.

34. Song HY, Jung HY, Park SI, Kim SB, Lee DH, Kang SG, Il Min Y. Covered retrievable expandable nitinol stents in patients with benign esophageal strictures:initial experience. Radiology 2000;217:551-7.

35. Saito Y, Tanaka T, Andoh A, Minematsu H, Hata K, Tsujikawa T, Nitta N,. Usefulness of biodegradable stents constructed of poly-l-lactic acid monofi laments in patients with benign esophageal stenosis . World J Gastroenterol 2007;13:3977-80.

36. Siersema PD, Homs MY, Haringsma J, Tilanus HW, Kuipers EJ. Use of large-diameter metallic stents to seal traumatic nonmalignant perforations of the esophagus. Gastrointest Endosc 2003;58:356-61.

37. Johnsson E, Lundell L, Liedman B. Sealing of esophageal perforation or ruptures with expandable metallic stents: a prospective controlled study on treatment effi cacy and limitations. Dis Esophagus 2005;18:262-6.

38. Freeman RK, Van Woerkom JM, Ascioti AJ. Esophageal stent placement for the treatment of iatrogenic intrathoracic esophageal perforation. Ann Th orac Surg 2007;83:2003-7.

39. Chung MG, Kang DH, Park DK, ParkJJ, Park HC, Kim JH. Successful treatment of Boerhaave's syndrome with endoscopic insertion of a self-expandable metallic stent: report of three cases and a review of the literature. Endoscopy 2001;33:894-7.

40. Petruzziello L, Tringali A, Riccioni ME, Mutignani M, Margaritora S, Cesario A, Costamagna G. Successful early treatment of Boerhaave's syndrome by endoscopic placement of a temporary self-expandable plastic stent without $\mathrm{fl}$ uoroscopy. Gastrointest Endosc 2003 ;58:608-12.

41. van Heel NCM, Haringsma J, Spaander MCW, Bruno MJ, Kuipers EJ. Short-term esophageal stenting in the management of benign perforations. Am J Gastroenterol 2010; 105:1515-20.

42. Schubert D, Scheidbach H, Kuhn R, Wex C, Weiss G, Eder F, Lippert H. Endoscopic treatment of thoracic esophageal anastomotic leaks by using silicone-covered, self-expanding polyester stents. Gastrointest Endosc 2005;61:891-6.

43. Langer FB, Wenzl E, Prager G, Salat A, Miholic J, Mang T, Zacherl J. Management of postoperative esophageal leaks with the Polyflex self-expanding covered plastic stent. Ann Thorac Surg 2005;79:398-403.

44. Eleft heriadis E, Kotzampassi K. Temporary stenting of acquired benign tracheoesophageal fistulas in critically ill ventilated patients. Surg Endosc 2005;19:811-5.

45. G Wright, H Lewis, B Hogan, Burroughs A, Patch D, O'Beirne J. A self-expanding metal stent for complicated variceal hemorrhage: experience at a single center. Gastrointest Endosc 2010;71:71-78.

Source of support: Nil; Conflict of interest: none declared 